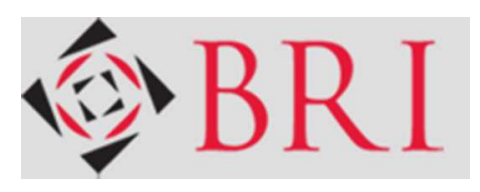

\title{
The new governance for low-carbon buildings: Mapping, exploring, interrogating
}

\begin{tabular}{|r|l|}
\hline Journal: & Building Research \& Information \\
\hline Manuscript ID & 15BR0622-RE.R2 \\
\hline Manuscript Type: & Research Paper \\
\hline Keywords: & $\begin{array}{l}\text { environmental performance, governance, building regulations, low-carbon } \\
\text { buildings }\end{array}$ \\
\hline Other keywords: & new governance \\
\hline Abstract: & $\begin{array}{l}\text { Acknowledging the limitations of traditional, mandatory governance } \\
\text { instruments (building codes, planning legislation) to achieve low-carbon } \\
\text { buildings, governments, firms and other organisations have been } \\
\text { experimenting with alternatives. This trend has become known as the 'new } \\
\text { governance'. This article brings together 50 new governance instruments } \\
\text { to better understand what this new governance for low-carbon buildings } \\
\text { looks like, and what may be expected from it. It finds that new governance } \\
\text { instruments fall short in exactly the same areas as do traditional } \\
\text { instruments. It argues for a change in application of new governance } \\
\text { instruments along three paths to improve their performance. }\end{array}$ \\
\hline
\end{tabular}


1

2

3

4

5

6

7

8

9

10

11

12

13

14

15

16

17

18

19

20

21

22

23

24

25

26

27

28

29

30

31

32

33

34

35

36

37

38

39

40

41

42

43

44

45

46

47

48

49

50

51

52

53

54

55

56

57

58

59

60
TITLE PAGE

The new governance for low-carbon buildings: Mapping, exploring, interrogating

\section{Author}

Dr. Jeroen van der Heijden

Associate Professor

Australian National University and University of Amsterdam

j.j.vanderheijden@anu.edu.au 
ABSTRACT, KEYWORDS, ACKNOWLEDGEMENTS

\begin{abstract}
Acknowledging the limitations of traditional, mandatory governance instruments (building codes, planning legislation) to achieve low-carbon buildings, governments, firms and other organisations have been experimenting with alternatives. This trend has become known as the 'new governance'. This article brings together 50 new governance instruments to better understand what this new governance for low-carbon buildings looks like, and what may be expected from it. It finds that new governance instruments fall short in exactly the same areas as do traditional instruments. It argues for a change in application of new governance instruments along three paths to improve their performance.
\end{abstract}

\title{
Keywords
}

Environmental performance, governance, low-carbon buildings, building regulations

\section{Acknowledgements}

This article was supported by a VENI-grant from the Netherlands Organisation for Scientific Research (NWO; grant number 45111015) and a DECRA-grant from the Australian Research Council (grant number DE15100511). The article builds on a research project that is discussed in more detail in Van der Heijden (2014). The current article presents the main findings from this larger project, and expands it by presenting a number of ideas that may help policymakers to move beyond the limitations of new governance for low-carbon buildings. Many thanks to three anonymous reviewers for suggested changes to an earlier version of the manuscript. Special thanks to Shane Chalmers for proofreading and earlier version of this article. 
The new governance for low-carbon buildings: Mapping, exploring, interrogating

\section{Introduction}

Traditional building codes and planning legislation are ill-suited to accelerate the transition to lowcarbon buildings. The main problems relate to the long time it takes to develop buildings codes and planning legislation; the tendency to exempt existing buildings from complying with new or mandated codes and legislation; and the difficulty of addressing user behaviour through them. In response, governments, firms, and other organisations have been trialling alternative and complementary governance instruments for some decades now. Examples include certification and classification of buildings, new forms of financing, and innovative ways of generating and disseminating information. The larger policy experiment of trialling alternative governance instruments has become known as 'new governance' (Holley, Gunningham, \& Shearing, 2012; Wurzel, Zito, \& Jordan, 2013).

This new governance fits a broader transition from traditional state-led direct regulatory interventions to governance approaches that allow for a broad inclusion of non-state stakeholders and the use of less-coercive regulatory instruments. Often new governance instruments blend command-and-control type approaches with newer voluntary mechanisms, and they are normally added as complements to existing regulatory frameworks. But what exactly does this new governance for low-carbon buildings look like around the globe? Given the popularity of new governance for low-carbon building development and transformation it is of relevance to understand the scope of the new governance instruments' designs, why they were introduced, how they perform, and whether better outcomes may be expected of them than of traditional building codes and planning legislation.

This article seeks to map, explore and interrogate this new governance for low-carbon buildings by drawing together insights from 50 new governance instruments from Australia, Asia, Europe and North America. It finds that these are predominantly applied at the very top end of the construction and property sector; that their uptake is limited, particularly in the area of existing buildings; and that they have a strong focus on building technology but appear less interested in changing the behaviour of building users.

\section{Complications of governing low-carbon buildings}

The construction, maintenance and use of buildings account for 40 per cent of global energy consumption and 35 per cent of global carbon emissions-of which 80 per cent relates to the operational phase for heating, cooling, and ventilating buildings as well as for operating appliances. 
Building-related energy consumption is split roughly evenly between the residential and commercial property sectors (IPCC, 2014; US Energy Information Administration, 2013-there is some debate about these numbers; for detailed discussions see Majeau-Bettez et. Al, 2011; Crawford \& Stephan, 2013). In short, buildings and how we use them contribute considerably to the process of humaninduced climate change.

At the same time buildings hold a considerable mitigation potential. Technologies and design solutions are available that allow for cost-effective reductions of carbon emissions of 30 to 80 per cent (IPCC, 2014; Mumovic \& Santamouris, 2013). Likewise, much knowledge is available on how changes to building user behaviour can reduce energy consumption and related carbon emissions (Cabinet Office, 2011). The question is, then, how to ensure that technology, design solutions, and insights on behavioural change are taken up on a large scale and in a timely manner?

An obvious answer to that question would be: Let governments introduce mandatory requirements. Governments have, after all, a long history of regulating buildings through building codes and planning legislation, and these traditional governance instruments have contributed to a relatively safe and healthy built environment-albeit these privileges are not shared equally around the globe (Taylor, 2013). And indeed, governments have sought, and to some extent achieved, improved building energy efficiency and reduced building carbon intensity through buildings codes since the 1970s (IEA, 2013). Unfortunately building codes and planning legislation come with a number of constraints that hamper a rapid and large scale transition towards low-carbon buildings. To name a few (UN, 2014; UNEP, 2007; World Bank, 2011):

- It often takes a long time to develop and implement mandatory requirements due to the many checks and balances required to ensure democratic accountability and transparency. This sometimes results in situations where mandatory requirements cannot keep up with technological developments and hamper their uptake.

- Proposals for change of mandatory regulation easily become politicised due to vested interests and sunk-costs in the construction and property sectors. Policymakers take high risks in proposing ambitious (amendments to) mandatory requirements for low-carbon buildings, and if they do they often face a long process of lobbying and being lobbied.

- The development and implementation of mandatory requirements require substantial institutional capital-knowledgeable policymakers, bureaucrats to process regulations, inspectors to assess building plans and construction work, and so on. Particularly in rapidly developing economies, such institutional capital is often found to be lacking. This is problematic because this is where the fastest growth of the built environment is expected and where mandatory requirements currently are lowest. That being said, the enforcement 
of building energy efficiency codes is also problematic in developed economies because inspectors prioritise classic regulated areas (such as structural safety and healthiness) over the relatively novel area of resource efficiency and carbon intensity.

- New and amended mandatory requirements often exempt existing buildings from compliance-a process known as 'grandfathering'. This is problematic because today's built environment already contributes to unsustainable levels of carbon emissions. Grandfathering clauses reduce the impact of amended and new mandatory instruments, which is particularly challenging for developed economies. In these economies, the built environment transforms by at best 2 per cent per year-implying that 70 per cent of today's buildings will be still in use in 2050 .

- Finally, mandatory requirements address objects-building parts, buildings, precincts-and not the behaviour of people using buildings. It would be unheard of for a government to require its citizens to wear an extra jumper in winter when they feel cold instead of turning up the heating. User behaviour is, however, a key aspect to reduced energy consumption and carbon emissions of the built environment, as discussed above.

\section{A turn to new governance for low-carbon buildings}

These problems are acknowledged by governments, firms, and other organisations. Since the early 1990s they have been trialling alternative governance instruments, often as substitutes or compliments to traditional ones. Experimenting with alternative governance instruments is not unique to the area of low-carbon buildings. It fits a logical development in an ongoing philosophy of deregulation, government reforms, and a larger shift in rethinking the role of government in governing society (DeLeon, Rivera, \& Manderino, 2010; Sabel \& Zeitlin, 2011). This 'new governance $^{\prime 1}$ is particularly strong in the area of environmental and resource sustainability (Holley et al., 2012; Wurzel et al., 2013). At least three related trends distinguish this new governance from earlier approaches to governance. First, a shift away from sole-government authority in governing environmental problems towards the involvement of public and private sector stakeholders. Second, an interest in governance instruments that encourage self-organisation, market solutions or both as substitutes for or complements to mandatory command-and-control style instruments. Third, a shift towards instruments that reward voluntary compliance as opposed to enforcing mandated

\footnotetext{
${ }^{1}$ Using the term 'new' when pointing out an empirical phenomenon is always risky. After a while it inevitably loses it 'newness'. This is also the case for new governance and new governance instruments: They have been trialled with for more than two decades and some of the new governance instruments studied-certification and classification, for example-have become fairly normal in the governing of low-carbon buildings.
} 
behaviour (for a comprehensive review of the new governance literature, see Van der Heijden, 2013).

This article seeks to better understand this shift towards new governance for low-carbon building development and transformation. It brings together insights from 50 real world new governance instruments from around the globe. I have studied these as part of a larger multi-year project that seeks to better understand new forms of governance for urban sustainability (Van der Heijden, 2014). Whilst the number of instruments examined in this article is substantial, by no means do I claim that it is a perfectly representative picture of all new governance activity for lowcarbon buildings around the globe. The set is comprehensive enough to provide a window on the larger policy experiment of trialling these new governance instruments that allows addressing the questions introduced at the start of this article (for a comparable research design to study new governance instruments see Hoffmann, 2011).

Instruments were initially identified through an extensive Internet search using keywords such as 'sustainable development AND [country]', 'sustainable building AND [country]', 'green building AND [country]', 'sustainable construction AND [country]' and 'green construction AND [country]'. In addition, I used social media (predominantly, sustainable and 'green' building groups on Linkedln) and my network of policymakers, administrators, architects, engineers, constructors, developers, investors and the like, in Australia, India, Malaysia, the Netherlands, Singapore, and the United States, to gain additional information about potential cases identified in this Internet search. This network was further explored for additional potential cases to study. The 50 instruments discussed in this article were selected from the larger pool of instruments I have uncovered based on two selection criteria. The first selection criterion relates to case variance and coverage. In this article I seek to present the richness of new governance instrument designs for low-carbon buildings. As such I have selected cases to represent the breadth of instrument design. At the same time I wish to highlight some general patterns that come out of my research in terms of instrument design. This relates to the four general types of instruments that I discuss in what follows. I have selected instruments from the larger pool to ensure that every type is illustrated with sufficient examples. The second selection criterion relates to availability and quality of information about the cases studied. This follow's Bent Flyvbjerg's (2015) notion of information-oriented case selection, which implies that cases are selected to maximize the utility of information from relatively small numbers of cases. The pool of 50 instruments presented here allows me to present narratives of individual examples and types, as well as a larger narrative of the opportunities and constraints of new governance instruments for low-carbon buildings. 
Relevant data for the analysing the instruments was obtained from websites, existing reports, and other documented sources. Novel data was obtained through a series of in-depth faceto-face elite interviews carried out between 2012 and 2014 (with a number of follow-up interviews in 2015). These interviews aimed to fill in gaps in the data from other sources, to resolve conflicts in data from other sources, and to gain additional insight in the instruments under scrutiny. Interviewees were traced through additional Internet searches and through social-network websites, again particularly LinkedIn. This resulted in a pool of over 200 interviewees from various backgrounds, including policymakers, administrators, architects, engineers, constructors, developers, and investors. The data were processed by means of a systematic coding scheme and qualitative data analysis software (Atlas.ti). By using this approach the data were systematically explored to gain an understanding of the performance of the instruments studied. That said, the insights provided in the article predominantly built on data obtained from websites, existing reports, and other documented sources (for a more extensive discussion of the methodology underlying this research project, see van der Heijden, 2014, 165-175).

It goes without saying that an article length contribution is too short to discuss each of these 50 instruments in depth. In what follows I therefore introduce the dominant types of instruments and provide examples for illustrative purposes. The online Appendix provides a brief description of each instrument (Table A) and a summary of the main characteristics of the instruments (Table B); for each instrument a hyperlink is provided for interested readers to follow up on (Table A). ${ }^{2}$ It also goes without saying that the boundaries of the different instrument types overlap. The types that are introduced in what follows are ideal-types. Real world instruments might have characteristics of more than one ideal-type.

\section{Certification and classification instruments}

The dominant type of new governance instruments for low-carbon buildings is certification and classification (Cole \& Valdebenito, 2013; Fowler \& Rauch, 2006). In general, such instruments allow for the assessment of buildings against a number of criteria. If these are met a certificate is issued to indicate compliance. Its application for low-carbon buildings comes with a specific twist: classification (Pérez-Lombard, Ortiz, González, \& Maestre, 2009). Classification allows for indicating relative performance of buildings within the same certification instrument. Three forms of classification are identified (Pérez-Lombard et al., 2009):

- Benchmarking, which indicates that a building, building part, or even building users meet the rules of that instrument. An example is Eco-Office in Singapore; an instrument that assesses

\footnotetext{
${ }^{2}$ LINK TO ONLINE APPENDIX ABOUT HERE.
} 
office users' energy, water, and paper consumption against a baseline and issues a certificate if that baseline is met. The instrument does not distinguish based on different classes of certification.

- Rating, which uses the relative performance of a building within the set of buildings certified to classify the building within that set. Identifiers such as stars or colours are often used to indicate this relative performance-the higher its relative performance compared to other certified buildings, the higher the number of stars awarded, indicating the specific class of certification. An example is NABERS (the National Australian Built Environment Rating System). It assess the energy performance or water performance of buildings, and issues certificates in six classes using a star rating to highlight differences among certified buildings. If a building is certified for energy and water performance, two different certificates are issued.

- Labelling, which builds on a holistic approach to classification. It does not certify energy efficiency or water consumption or carbon intensity individually, but seeks seek to classify buildings based on overall performance. Well known instruments such as BREEAM (BRE Environmental Assessment Method) and LEED (Leadership in Energy and Environmental Design) award credits for different sustainability credentials and the total number of credits awarded is the basis for the class of certification.

Differences in classification might raise information barriers, rather than reduce them. Various studies highlight that it is next to impossible to compare the performance of distinct certification and classification instruments simply because they are built on a different form of classification, or because the rules underlying the classification system are so diverse that a similar building could achieve a low class of certification in one instrument, but a high class of certification in another (Roderick, McEwan, Wheatley, \& Alonso, 2009; Van der Heijden, 2015).

To complicate things further, different forms of certification exist: 'as designed', 'as built' and 'in operation'. The first form certifies expected performance of a building design, the second form certifies the performance of a building built in compliance with that design, and the final form certifies achieved performance after a specified period of use-it is often subject to periodical renewal. The first two forms are dominant, and the latter form was developed in response to critiques of these two: buildings are often not built in compliance with their (certified) design; during construction many flaws might be made that instrument administrators or their inspectors do not notice; or user behaviour may undo the low-carbon credentials of a building-all of which could result in a certified design or completed building not meeting its expected performance. Such 
problems are often reported in the literature, as are problems of developers and property owners gaming the instruments by seeking easy but not necessarily low-carbon solutions to achieve high classes of certification (Scofield, 2013).

Certification and classification instruments have, thus far, achieved most promising results in the area of high-profile new commercial building development (such as offices in central business districts of major cities; Van der Heijden, 2015). It is here where developers and property owners expect (and get) high returns on their investments. These instruments have thus far been less successful in changing the market for residential buildings and existing buildings-but they also have not had a transformative impact in the area of less prestigious commercial building development (Yudelson \& Meyer, 2013). Moreover, when looked at in relative numbers the overall performance of this type of instruments is not too promising: Even one of the best performing instruments in the world, LEED in the United States, has over the course of 15 years certified less than 4 per cent of all new commercial property developed in that period. ${ }^{3}$

\section{Information generation and dissemination instruments}

A second type of instruments seeks to generate and disseminate knowledge on how to construct and retrofit low-carbon buildings, and how building users' behaviour can be modified to achieve reduced energy consumption. A typical example is Green Lights in the United States, implemented by the United States Environmental Protection Agency in the early 1990s (EPA, 1994). Through Green Lights the Agency sought to overcome initial resistance to and unfamiliarity with energy efficient lightning. It made visible to building users the ease of reducing energy consumption and supported them in generating knowledge relevant for running their business: cost savings. Green Lights participants committed to installing energy efficient lighting in 90 per cent of their facilitiesbut only where this was profitable to do so. In return the Environmental Protection Agency provided participants with tools (software predominantly) to carry out assessments and keep track of energy savings, helped them connect with lighting retrofitting services, and pointed out potential funding opportunities. Green Lights has witnessed a wide uptake throughout the United States, making it easier for participants to reduce operation costs and to brand themselves as environmentally aware (Moon, Bae, \& Jeong, 2014; Videras \& Alberini, 2000). It is now incorporated in Energy Star Buildings, a certification and classification instrument.

Besides supplying information directly from instrument-administrators to instrumentparticipants some instruments challenge participants to generate information on how to develop, retrofit, and use low-carbon buildings and share this information with instrument-administrators

\footnotetext{
${ }^{3}$ Data from www.usgbc.org and www.census.gov (7 July 2015).
} 
and other participants (Gollagher \& Hartz-Karp, 2013). The Better Building Partnership in Sydney's central business district is a clear example. It brings together Sydney's 14 major property owners and the city government and aims for significant building related carbon emission reductions through, among others, building energy retrofits. The combined building stock of these property owners is responsible for 50 per cent of all carbon emissions of the business district. Under the Partnership the property owners and the city government seek to reduce carbon emissions by 70 per cent by 2030 . The Partnership was launched in 2011 and by 2015 it was already halfway towards its envisioned target (Better Buildings Partnership, 2015). By working closely together and sharing knowledge on how they have upgraded their individual property, all participating property owners gain from each other's experiences.

Information generation and dissemination instruments appear most promising in exactly these two situations-broad instruments that set low and relatively easy requirements and provide considerable (financial) gains for participants, and elite instruments that set challenging requirements and provide considerable collective gains for participants (Van der Heijden, 2016). In other situations less successful outcomes are reported. The United States based Better Buildings Challenge, for example, is an instrument that seeks to incentivise participants to reduce the energy consumption of their offices by 20 per cent over a ten year period and share their experiences. In return they are supported by the United States Department of Energy to acquire the funds needed to retrofit their buildings. This instrument was also launched in 2011 and by 2015 some 32,000 buildings were participating. Whilst this number appears impressive, it reflects only 0.5 per cent of the close to 6 million commercial buildings in the United States. ${ }^{4}$

\section{Financing instruments}

A third type of new governance instruments for low-carbon buildings are particularly concerned with financing. Property developers and property owners often face difficulties in obtaining funds for the development or retrofitting of low-carbon buildings. Banks and other fund providers are concerned that the additional costs that (may) come with developing low-carbon buildings will not be represented in these buildings' future market value, and fear that lenders will not be able to pay back loans provided. The idea that future financial gains of low-carbon buildings-reduced operation costs, among others-improve these owners' ability to pay back loans does not fit current business models that are based on cash flows from production - and not reduced consumption-and growth (World Bank, 2011). Likewise, building owners might be concerned they will not see a return on their investments in low-carbon buildings because they do not own a property long enough, or they might

\footnotetext{
${ }^{4}$ Data from www.census.gov (7 July 2015).
} 
not value long-term gains over short-term costs-known as hyperbolic discounting (Ameli \& Brandt, 2015).

A variety of instruments addresses these issues. Revolving loan funds are one of these. Revolving loan funds for low-carbon buildings often consist of a sum of money that is lent to property developers and property owners to fund low-carbon building solutions. The assumption is that these solutions result in reduced operation costs of buildings, allowing owners to pay back the loan. Once the fund has recouped the money it can lend it again to others (Boyd, 2013). The Billion Dollar Green Challenge is one of the most ambitious examples of revolving loan funds. It challenges educational organisations, predominantly universities and colleges, in the United States to invest a total of $\$ 1$ billion in self-managed revolving funds to finance energy-efficiency upgrades of their buildings. By participating in the Challenge these organisations are supported in managing their funds, and share information on how to carry out energy-efficiency upgrades (Green Billion, 2013). The instrument was launched in 2011 and by 2015 it has attracted 52 participating organisations, who together have committed $\$ 114$ million to the Challenge-again not outstanding performance, keeping in mind there are about 5,300 universities and colleges in the United States. ${ }^{5}$

Other financing instruments are built on climate bonds or related forms of tripartite financing. The instrument 1200 Buildings in Melbourne, for example, builds on tripartite financing. As of 2009, it allows the city government to act as a 'middle person' between finance providers and commercial property owners that seek funds for building retrofits. The city government lends funds and supplies these to building owners-who commit to reduce their buildings' carbon emissions by at least 38 per cent-and recoups the loan through a special property tax. In doing so the city government takes away the risk experienced by the finance provider. A comparable example is Property Assessed Clean Energy (PACE) launched in 2008 in the United States. The instrument allows (local) governments to issue bonds to fund building retrofits and supply funds to property owners. Funds are, again, recouped through a property tax. The instrument initially sought to finance retrofits of commercial and residential buildings, but the subprime mortgage crisis has dealt a major blow. United States mortgage authorities no longer finance mortgages for upgrades of residential buildings under the instrument. Neither instrument has achieved impressive results yet: By 2015, less than 50 buildings were participating in 1200 Buildings, and PACE has resulted in some 350 retrofitted commercial buildings throughout the United States.

It may very well be that 'just' supporting property owners in finding financing is not the answer to the more fundamental question why property owners do not want to retrofit their

\footnotetext{
${ }^{5}$ Data from: www.washingtonpost.com/news/grade-point/wp/2015/07/20/how-many-colleges-anduniversities-do-we-really-need/ (19 December 2015).
} 
existing buildings or demand low-carbon new buildings in the first place. Another example of a financing instrument is illustrative here. In 1995 the United States Federal Housing Administration implemented the Energy Efficient Mortgage Program. The Program allows (future) home owners to borrow additional funds to improve the energy-efficiency of their (future) home. Home owners are, however, hardly interested in the Program: In its best year thus far, 2011, out of close to 15 million mortgages issued throughout the United States a mere 1,065-about 1 in 15,000-was issued under the Program (Federal Housing Administration, 2014). Home owners are found reluctant to undertake energy-efficiency retrofits of their homes, and those who are interested often have funds for retrofits or consider the paperwork and other related administrative efforts too much hassle for the relatively small (additional) mortgage provided through the Program (Kolstad, 2014).

\section{Accelerators and bridging instruments}

A fourth and final type of instruments seeks to accelerate the uptake of the earlier ones discussed, and seeks to bridge different instruments (traditional and new ones) aiming for synergies that make the whole of governance instruments for low-carbon buildings larger than the sum of its parts. Examples of accelerators are a range of incentives in place that seek to speed up the application of certification and classification instruments such as BREEAM and LEED. Some counties and cities in North Carolina give density bonuses, for example, to builders who comply with LEED criteria, and other states have in place tax incentives for construction work that receives LEED certification. Likewise, the Dutch government has in place Sustainable Public Procurement criteria that require that future government buildings or office space needs to be BREEAM certified or meet standards comparable to BREEAM certification. Other examples are the City of New York's 1000 Superintendents and the Australian Supply Chain Sustainability. Both instruments seek to (re)educate specific actors in the construction and property sectors about the advantages of lowcarbon buildings. 1000 Superintendents builds on the assumption that through interactions with property owners and tenants, superintendents might be able to change their mindset about lowcarbon buildings and ways to reduce building energy consumption.

To give an example of a bridging instrument: The participants of the Better Building Partnership in Sydney are experimenting with green leases as a bridge between property owners participating in new governance instruments and tenants participating in other instruments. A green lease is, like any lease, an agreement between a property owner (landlord) and a tenant, but it includes specific clauses about both parties' responsibilities for low-carbon and other (environmental) sustainability credentials of a building. What participants of the Partnership realised is that property owners often need the commitment of their tenants to use a low-carbon building in 
a specific manner to maintain, for instance, a high level of 'in operation' certification under a certification and classification instrument. At the same time tenants might need their landlord to make changes to their building when they participate in an instrument such as Eco-Office in Singapore-after all, there is only so much they can do through changed user behaviour in terms of energy reduction. Without commitment from the other party, landlords or tenants might refrain from participating in these instruments. By promoting green leases throughout Australia, the participants of the Partnership hope these problems can be overcome (Blundell, 2014).

\section{Four new governance trends}

From exploring and mapping new governance instruments for low-carbon buildings, it has become clear there is no shortage of these instruments. They come in a wide range of designs and are implemented in a variety of settings (see further the online Appendix). At first glance they appear hopeful complements to traditional, mandatory governance instruments such as building codes and planning legislation because they are often tailored to a specific problem, move beyond the onesize-fits-all approach of traditional instruments, and include the relevant actors to address that problem and utilise their tacit knowledge. That being said, the 50 instruments studied point to four trends that raise questions about the overall ability of new governance instruments to accelerate a rapid and large transition to low-carbon buildings (see also Table $B$ in the online Appendix):

- Whilst the number of these new governance instruments is vast, their overall impact is limited. Even the most widely applied instruments, certification and classification instruments such as LEED and BREEAM, have achieved a marginal uptake in their potential market at best. This holds for the vast majority of instruments studied. The vast majority of instruments has not yet been able to move beyond the absolute leaders in the construction and property sectors.

- The majority of instruments studied has a sole focus on or dominant application in the highend of the commercial property market: Office buildings in central business districts of major cities and government owned and leased property. This holds particularly for certification and classification instruments. Whilst these instruments allow for certification of other building types, including residential buildings, they face difficulties penetrating these other markets (Cole \& Valdebenito, 2013). There appears a clear logic to why new governance instruments are dominant in the high-end of the commercial property-market: These are the buildings commissioned and leased by relatively large firms to whom leadership matters, who have in place social corporate responsibility policies, and who have to justify their behaviour to internal and external stakeholders. They are more likely to demand low-carbon 
buildings and are more willing to pay a premium for these than smaller firms and households who do not face such pressures (Dixon, Ennis-Reynolds, Roberts, \& Sims, 2009).

- Whilst the instruments studied focus evenly on new and existing buildings, the uptake of instruments with a focus on existing buildings is worse than for those with a focus on new buildings. Two issues stand out. First, even when a landlord can acquire funds to retrofit a building she might be held back in doing so because of the typical split-incentive problemthe gains of the retrofit come to the tenant, but the landlord has to bear the costs (Hakkinen \& Belloni, 2011). Green leases could help landlords overcome this problem, but financing instruments often have a sole focus on financing retrofits-1200 Buildings in Melbourne and PACE in the United States are typical examples. Second, particularly for small and medium sized firms and households the process of going through a retrofit might be too much trouble to make up for the longer term gains. This 'hassle factor' is not addressed by the instruments studied (cf., Cabinet Office, 2011).

- A final trend that stands out is that the majority of instruments studied seek to reduce the carbon intensity and energy consumption of buildings through technology. Only a few seek improvements through behavioural change of building users. The research did not suggest a clear explanation for this trend. It could be that a larger paradigm of ecological modernisation, popular in many of the countries that provide contexts for these instruments, skews governments, firms, and other organisations towards thinking in terms of technological solutions instead of behavioural ones (Hayden, 2014). Another explanation is that most instruments focus on 'per square meter' performance of a building, and not on a 'per capita' basis (Janda, 2011; Stephan \& Crawford, 2014). ${ }^{6}$ A less prosaic explanation would be that firms producing technological solutions drive the new governance agenda because they have a strong interest in seeing this type of instrument implemented. Future research may wish to further explore this area.

\section{Conclusion and discussion: Beyond the limitations of new governance for low-carbon buildings}

It goes without saying that the findings presented should be considered in the light of the approach taken to the research. The 50 instruments studied built on a stratified sample. It is likely that a broader variety of instruments may be found than the four ideal types discussed in this article. The paper is further biased towards discussing instruments from Australia and the United Statesroughly 60 per cent of instruments discussed are from these two countries (see Table $A$ in the online

\footnotetext{
${ }^{6}$ I thank one of the anonymous reviewers for this suggestion.
} 
Appendix). Studies from other countries may result in different findings. Also, this article has largely excluded the impact of instrument contexts from the analysis, and some of the generalisations presented here may not hold in specific instrument contexts. This is, ultimately, an issue for further research.

That having been said, the new governance for low-carbon buildings-illustrated by the sample of 50 instruments - appears most promising in the high-end of new commercial property development, and has limited impact in other areas of the construction and property sectors. It has achieved marginal results in the areas of residential buildings, existing buildings, and building user behaviour. This is problematic because these are the exact areas where traditional, mandatory governance instruments such as building codes and planning legislation also fail to deliver results.

Does this imply the new governance for low-carbon buildings should be considered a failed policy experiment? I think not. It has provided leaders in the construction and property sectors a context and means to showcase the possibilities in terms of low-carbon buildings. A wealth of bestpractices is now available that evidence the possibilities to design, construct, and use buildings in ways that result in considerable lower carbon emissions than conventional practice. These buildings and the media attention generated by new governance instruments help to change norms in the construction and property sectors and help to make low-carbon buildings less alien (Yudelson \& Meyer, 2013).

A shortcoming of new governance for low-carbon buildings, as a larger policy experiment, is that the focus has predominantly been on generating and showcasing leadership in the construction and property sectors. Time and again the mission statements of the instruments stress the need of illustrating that low-carbon buildings that move well beyond conventional practice are possiblewhether at net-cost benefit, with existing technology, within existing legal settings, through changed behaviour, or otherwise (see the various links to webpages in the online Appendix). What the instruments have in general failed to do, however, is think beyond attracting leaders and explore how they can move from leaders to other players in the construction and property sectors. At the end of the day it is relevant that the masses make a change, and not the leaders only.

How then can new governance instruments be used to accelerate a large scale transition to low-carbon buildings? I see three complementary paths. The first is to rethink their purpose. The current generation of instruments is pre-occupied with generating and showcasing leadership, a second generation of instruments might wish to focus on taking the next step: Moving from leaders to other players. Future research may seek to better understand why other players are less enthusiastic about the new governance instruments. Do they face different barriers than leaders? Are they less interested than leaders? Do they need different incentives than leaders? 
Understanding and addressing these questions should be the ambition of a next generation of new governance instruments.

The second path is to rethink these instruments' position in building regulatory frameworks at local, national, and international level. Most of the current instruments are voluntary in natureafter all, they built on the notion of incentivising leadership through positive rewards and not by enforcing leadership through penalties. A future generation of instruments might wish to move more to the mandatory space, or at least become less voluntary. Future research and future new governance instruments may wish to build more on the state of the art in the current governance literature. For example, what would happen if these instruments move from voluntary opting-in to voluntary opting-out (cf., Kosters \& van der Heijden, 2015)? This may improve the uptake of instruments such as the Energy Efficiency Mortgages in the United States. What would happen if participation becomes mandatory, but the level of performance remains voluntary? This resembles the design of the certification and classification instruments NABERS in Australia and Green Mark in Singapore, both showing considerable uptake and performance when compared to related instruments such as LEED in the United States and Green Star in Australia., ${ }^{7,8}$

The third path is to think more carefully about the interaction between new governance instruments and existing policy mixes. Where can they contribute or fill in gaps? Can positive synergies between new governance instruments and existing regulation be designed, and if so, how? Would it even be possible to introduce new governance instruments with the aim of utlimately replacing existing regulation and legislation? A challenging design would be to think of new governance instruments as part of rolling rule regimes (cf., Sabel, Fung, Karkkainen, Cohen, \& Rogers, 2000). Under such a regime, today's leading practice would be the future's mandatory bottom-line. This still rewards leaders as they have the opportunity to set the future bottom-line and have the experience with achieving it, but it would actively push others to follow suit within the time-frame set.

\footnotetext{
${ }^{7}$ Data from: www.nabers.gov.au (14 July 2015)

${ }^{8}$ Data from: www.greenmark.sg (14 July 2015)
} 


\section{References}

Ameli, N., \& Brandt, N. (2015). What Impedes Household Investment in Energy Efficiency and Renewable Energy? Paris: OECD Publishing.

Auld, G. (2014). Constructing Private Governance. Newhaven: Yale University Press.

Better Buildings Partnership. (2015). Better Buildings Partnership. Annual Report 2013-2014. Sydney: City of Sydney.

Blundell, L. (2014). The Tenants \& Landlords Guide to Happiness. Sydney: The Fifth Estate/Better Buildings Partnership.

Boyd, S. (2013). Financing and Managing Energy Projects Through Revolving Loan Funds. Sustainability, 6(6), 345-352.

Cabinet Office. (2011). Behaviour change and energy use. London: Cabinet Office.

Crawford, R. \& Stephan, A. (2013) The significance of embodied energy in certified passive houses. ICCBM 2013: International Conference on Construction and Building Materials, Copenhagen, 13-14 June, 473-479

Cole, R., \& Valdebenito, M. J. (2013). The importation of building environmental certification systems: international usages of BREEAM and LEED. Building Research \& Information, 41(6), 662-676.

DeLeon, P., Rivera, J., \& Manderino, L. (2010). Voluntary Environmental Programs: An Introduction. In P. DeLeon \& J. Rivera (Eds.), Voluntary Environmental Programs (pp. 1-10). Plymouth: Lexington Books.

Dixon, T., Ennis-Reynolds, G., Roberts, C., \& Sims, S. (2009). Is there a demand for sustainable offices? An analysis of UK business occupier moves. Journal of Property Research, 26(1), 6185.

EPA. (1994). EPA's financial management status report \& five-year plan. Washington: U.S. Environmental Protection Agency.

Federal Housing Administration. (2014). Annual Management Report: Fiscal year 2014. Washington, D.C.: U.S. Department of Housing and Urban Development.

Flyvbjerg, B. (2015). Making Social Science Matter. 17th edition. Cambridge, Cambridge University Press.

Fowler, K. M., \& Rauch, E. M. (2006). Sustainable Building Rating Systems. Retrieved from Washington: http://www.pnl.gov/main/publications/external/technical_reports/PNNL15858.pdf

Gollagher, M., \& Hartz-Karp, J. (2013). The Role of Deliberative Collaborative Governance in Achieving Sustainable Cities. Sustainability, 5(6), 2343-2366.

Green Billion. (2013). The Billion Green Dollar Challenge. Retrieved from http://greenbillion.org/

Hakkinen, T., \& Belloni, K. (2011). Barriers and drivers for sustainable building. Building Research \& Information, 39(3), 239-255.

Hayden, A. (2014). When Green Growth is Not Enough: Climate Change, Ecological Modernization, and Sufficiency. Quebec: McGill-Queen's University Press.

Holley, C., Gunningham, N., \& Shearing, C. (2012). The New Environmental Governance. London: Routledge.

Hoffmann, M. (2011). Climate Governance at the Crossroads. Oxford, Oxford University Press. IEA. (2013). Modernising Building Energy Codes. Paris: United Nations Development Programme. IPCC. (2014). Climate Change 2014: Impacts, Adaptation, and Vulnerability. Cambridge: Cambridge University Press.

Janda, K. (2011) Buildings don't use energy: people do. Architectural Science Review, 54 (1), 15-22.

Kolstad, L. (2014). Designing a Mortgage Process for Energy Efficiency. Washington, D.C.: American Council for an Energy-Efficient Economy.

Kosters, M., \& van der Heijden, J. (2015). From mechanism to virtue: Evaluating Nudge theory. Evaluation, 21(3), 276-291. 
Majeau-Bettez, G., Strømman, A. \& Hertwich, E. (2011) Evaluation of process- and input-outputbased life cycle inventory data with regard to truncation and aggregation issues.

Environmental Science \& Technology, 45 (23), 10170-10177.

Moon, S.-G., Bae, S., \& Jeong, M.-G. (2014). Corporate Sustainability and Economic Performance: an Empirical Analysis of a Voluntary Environmental Program in the USA. Business Strategy and the Environment, 23(8), 534-546.

Mumovic, D., \& Santamouris, M. (2013). A Handbook of Sustainable Building Design and Engineering. Abingdon: Routledge.

Pérez-Lombard, L., Ortiz, J., González, R., \& Maestre, I. R. (2009). A review of benchmarking, rating and labelling concepts within the framework of building energy certification schemes. Energy and Buildings, 41(3), 272-278.

Roderick, Y., McEwan, D., Wheatley, C., \& Alonso, C. (2009). A comparative study of building energy performance assessment between LEED, BREEAM and Green Star schemes. Paper presented at the Building Simulation 2009, Glasgow.

Sabel, C., Fung, A., Karkkainen, B., Cohen, J., \& Rogers, J. (2000). Beyond Backyard Environmentalism. Boston: Beacon Press.

Sabel, C., \& Zeitlin, J. (2011). Experimentalist Governance. In D. Levi-Faur (Ed.), The Oxford Handbook of Governance (pp. 169-185). Oxford: Oxford University Press.

Scofield, J. (2013). Efficacy of LEED-certification in reducing energy consumption and greenhouse gas emissions for large New York City office buildings. Energy and Buildings, 67, 517-524.

Stephan, A. \& Crawford, R. (2014) A comprehensive life cycle water analysis framework for residential buildings. $B R I, 42(6), 685-695$.

Taylor, P. (2013). Extraodrinary Cities: Millennia of Moral Syndromes, World-Systems and City/State Relations. Cheltenham: Edward Elgar.

UN. (2014). World Urbanization Prospects: The 2014 Revision. New York: United Nations.

UNEP. (2007). Buildings and Climate Change. Status, Challenges and Opportunities. Paris: United Nation Environment Programme.

US Energy Information Administration. (2013). International Energy Outlook. Washington: US Energy Information Administration.

Van der Heijden, J. (2013). Looking forward and sideways: Trajectories of new governance theory. Amsterdam Law School Research Paper No. 2013-04, General Subserie Research Paper No. 2013-01. Available online: http://papers.ssrn.com/sol3/papers.cfm?abstract id=2204524

Van der Heijden, J. (2014). Governance for Urban Sustainability and Resilience: Responding to Climate Change and the Relevance of the Built Environment. Cheltenham: Edward Elgar.

Van der Heijden, J. (2015). On the potential of voluntary environmental programmes for the built environment: A critical analysis of LEED. Journal of Housing and the Built Environment, 30(4), 553-56.

Van der Heijden, J. (2016). Experimental governance for low-carbon buildings and cities: Value and limits of local actions networks. Cities. Early view available online. DOI: 10.1016/j.cities.2015.12.008.

Videras, J., \& Alberini, A. (2000). The appeal of voluntary environmental programs: which firms participate and why? Contemporary Economic Policy, 18(4), 449-461.

World Bank. (2011). Climate Change and the World Bank Group: The Challenge of Low-Carbon Development. Washington, D.C.: The World Bank.

Wurzel, R., Zito, A., \& Jordan, A. (2013). Environmental Governance in Europe. Cheltenham: Edward Elgar.

Yudelson, J., \& Meyer, U. (2013). The World's Greenest Buildings. Abingdon: Routledge. 
Tables

Table A - 50 'new governance' instruments for low-carbon buildings

1000 Supers Voluntary education program that trains superintendents in the practice of (New York, building energy efficiency operations.

United States; http://training.32bjfunds.com/en-us/green/theprogram.aspx

2012)

1200 Buildings Tripartite financing for commercial building retrofits.

(Melbourne, http://1200buildings.com.au

Australia;

2010)

Amsterdam

Revolving loan fund managed by the City of Amsterdam.

Climate and http://akef.nl/en/

Energy Fund

(Amsterdam,

Netherlands;

2011)

Better

Information and technical support for commercial building retrofits. Also support

Buildings in acquiring funds for retrofits.

Challenge https://www4.eere.energy.gov/challenge/home

(United

States; 2011)

Better Partnership between the City of Sydney and commercial property owners

Building committed to improve their building energy-efficiency.

Partnership http://www.sydneybetterbuildings.com.au/

(Sydney,

Australia;

2011)

Billion Dollar Technical support for setting up self-managed revolving loan funds for building

Green energy-efficiency upgrades.

Challenge http://greenbillion.org/

(United

States; 2011)

BREEAM (BRE Certification and classification instrument based on labelling.

Environmental http://www.breeam.org/

Assessment

Method)

(global; 1990)

Building Competitive funding for demonstrating reduced carbon intensity of existing Innovation commercial buildings.

Fund $\quad$ https://www.sa.gov.au/topics/water-energy-and-environment/climate-

(South change/tackling-climate-change/what-organisations-business-and-industry-can-

Australia, do/building-innovation-fund

Australia;

2008) 
Table A - continued

\begin{tabular}{|c|c|}
\hline $\begin{array}{l}\text { Canadian } \\
\text { Renewable } \\
\text { and } \\
\text { Conservation } \\
\text { Expenses } \\
\text { (Canada; } \\
\text { 1996) }\end{array}$ & $\begin{array}{l}\text { Tax deduction for the upfront costs of developing and exploring the application } \\
\text { of renewable energy. } \\
\text { https://www.nrcan.gc.ca/energy/efficiency/industry/financial-assistance/5147 }\end{array}$ \\
\hline $\begin{array}{l}\text { Chicago Green } \\
\text { Office } \\
\text { Challenge } \\
\text { (Chicago, } \\
\text { United States; } \\
\text { 2008) }\end{array}$ & $\begin{array}{l}\text { Friendly competition among commercial building users (office tenants) to adopt } \\
\text { sustainable and low-carbon practices at work and home. } \\
\text { http://greenpsf.com/go/community/about/chicago }\end{array}$ \\
\hline $\begin{array}{l}\text { CitySwitch } \\
\text { Green Office } \\
\text { (Australia; } \\
\text { 2010) }\end{array}$ & $\begin{array}{l}\text { Technical support for and information sharing among office tenants about } \\
\text { energy-efficiency and waste-efficiency. } \\
\text { http://www.cityswitch.net.au/Home.aspx }\end{array}$ \\
\hline $\begin{array}{l}\text { Climate } \\
\text { Change Sector } \\
\text { Agreements } \\
\text { (South } \\
\text { Australia, } \\
\text { Australia; } \\
\text { 2007) }\end{array}$ & $\begin{array}{l}\text { Negotiated agreements between the Government of South Australia and local } \\
\text { businesses committed to reduce their carbon emissions. } \\
\text { https://www.sa.gov.au/topics/water-energy-and-environment/climate- } \\
\text { change/tackling-climate-change/what-organisations-business-and-industry-can- } \\
\text { do/climate-change-sector-agreements }\end{array}$ \\
\hline $\begin{array}{l}\text { ClimateSmart } \\
\text { Home Service } \\
\text { (Queensland, } \\
\text { Australia; } \\
\text { 2009) }\end{array}$ & $\begin{array}{l}\text { Information and technical support for households to reduce energy and water } \\
\text { consumption. Terminated in } 2012 \text {. } \\
\text { http://hopeaustralia.org.au/uploads/media/Article Climate Smart Home Servi } \\
\text { ce edited.pdf }\end{array}$ \\
\hline $\begin{array}{l}\text { Common } \\
\text { Carbon Metric } \\
\text { (global; 2010) }\end{array}$ & $\begin{array}{l}\text { Protocol for measuring energy use and reporting greenhouse gas emissions from } \\
\text { the operational phase of buildings. } \\
\text { http://www.unep.org/sbci/activities/ccm Pilot.asp }\end{array}$ \\
\hline $\begin{array}{l}\text { Density } \\
\text { Bonuses } \\
\text { North Carolina } \\
\text { (North } \\
\text { Carolina, } \\
\text { United States; } \\
\text { 2009) }\end{array}$ & $\begin{array}{l}\text { A number of jurisdictions in North Carolina allow builders who construct or } \\
\text { retrofit buildings that are LEED certified (see below) or meet comparable } \\
\text { requirement to build in higher densities than prescribed in planning legislation. } \\
\text { http://www.usgbc.org/Docs/Archive/General/Docs2021.pdf }\end{array}$ \\
\hline $\begin{array}{l}\text { E+Green } \\
\text { Building } \\
\text { (Boston, } \\
\text { United States; } \\
\text { 2011) }\end{array}$ & $\begin{array}{l}\text { Design competition for multi-unit housing that produce more energy than they } \\
\text { consume. } \\
\text { http://www.epositiveboston.org/ }\end{array}$ \\
\hline $\begin{array}{l}\text { Eco Housing } \\
\text { (Pune, India; } \\
\text { 2004) }\end{array}$ & $\begin{array}{l}\text { Certification and classification instrument based on labelling for new multi-unit } \\
\text { residential development. } \\
\text { http://ecohousing.in/Eco-Housing-for-PMC.php }\end{array}$ \\
\hline
\end{tabular}


Table A - continued

\begin{tabular}{|c|c|}
\hline $\begin{array}{l}\text { Eco-Office } \\
\text { (Singapore; } \\
\text { 2002) }\end{array}$ & $\begin{array}{l}\text { Certification and classification instrument based on benchmarking for office } \\
\text { tenants. } \\
\text { http://www.sec.org.sg/ecooffice/ }\end{array}$ \\
\hline $\begin{array}{l}\text { Energy } \\
\text { Efficiency } \\
\text { Mortgage } \\
\text { (United } \\
\text { States; 1995) }\end{array}$ & $\begin{array}{l}\text { Additional mortgage for funding energy-efficiency upgrades of new or existing } \\
\text { houses or housing units. } \\
\text { http://energy.gov/eere/slsc/energy-efficient-mortgages }\end{array}$ \\
\hline $\begin{array}{l}\text { Energy } \\
\text { Experience } \\
\text { Programme } \\
\text { (Singapore; } \\
\text { 2010) }\end{array}$ & $\begin{array}{l}\text { Educational program for secondary school students about energy consumption, } \\
\text { with a strong focus on building related energy consumption. } \\
\text { http://www.singaporepower.com.sg/irj/servlet/prt/portal/prtroot/docs/guid/b0 } \\
\text { 80b6ca-1a7d-2e10-daa1-dba2df443292?spstab=Energy\%20Efficiency }\end{array}$ \\
\hline $\begin{array}{l}\text { Energy Leap } \\
\text { (Netherlands; } \\
\text { 2010) }\end{array}$ & $\begin{array}{l}\text { Program to increase demand and supply of energy-efficient buildings. } \\
\text { http://energiesprong.nl/over-ons/wat-is-het/ (in Dutch only) }\end{array}$ \\
\hline $\begin{array}{l}\text { Energy Star } \\
\text { Buildings } \\
\text { (United } \\
\text { States; 1995) }\end{array}$ & $\begin{array}{l}\text { Certification and classification instrument based on rating for commercial } \\
\text { buildings. } \\
\text { https://www.energystar.gov/buildings }\end{array}$ \\
\hline $\begin{array}{l}\text { Energy Star } \\
\text { for Homes } \\
\text { (United } \\
\text { States; 1995) }\end{array}$ & $\begin{array}{l}\text { Certification and classification instrument based on rating for houses and } \\
\text { housing units. } \\
\text { https://www.energystar.gov/index.cfm?c=new homes.hm index }\end{array}$ \\
\hline $\begin{array}{l}\text { EnviroDevelop } \\
\text { ment } \\
\text { (Australia; } \\
\text { 2006) }\end{array}$ & $\begin{array}{l}\text { Certification and classification instrument based on benchmarking for new } \\
\text { houses and housing units. } \\
\text { http://www.envirodevelopment.com.au/ }\end{array}$ \\
\hline $\begin{array}{l}\text { Environmental } \\
\text { Upgrade } \\
\text { Agreements } \\
\text { (Sydney, } \\
\text { Australia; } \\
\text { 2011) }\end{array}$ & $\begin{array}{l}\text { Tripartite financing for commercial building retrofits. } \\
\text { http://www.environment.nsw.gov.au/business/upgrade-agreements.htm }\end{array}$ \\
\hline $\begin{array}{l}\text { ESCO } \\
\text { Accreditation } \\
\text { Scheme } \\
\text { (Singapore; } \\
\text { 2010) }\end{array}$ & $\begin{array}{l}\text { Certification and classification instrument based on benchmarking for energy } \\
\text { service companies (ESCOs). } \\
\text { http://www.e2singapore.gov.sg/Programmes/ESCO Accreditation Scheme.aspx }\end{array}$ \\
\hline $\begin{array}{l}\text { Green } \\
\text { Building } \\
\text { Incentive } \\
\text { Program } \\
\text { (San Diego, } \\
\text { United States; } \\
\text { 2012) }\end{array}$ & $\begin{array}{l}\text { Reduced plan check turnaround time and a } 7.5 \text { per cent reduction in plan check } \\
\text { and building permit fees for new construction projects that are LEED certified } \\
\text { (see below) or meet comparable requirements. } \\
\text { http://www.sandiegocounty.gov/pds/greenbuildings.html }\end{array}$ \\
\hline
\end{tabular}


Table A - continued

Green Certification and classification instrument based on labelling.

Building Index http://www.greenbuildingindex.org/

(Malaysia;

2009)

Green Tax credits for new construction and retrofitting projects that are LEED certified

Building Tax (see below) or meet comparable requirements. Terminated in 2012.

Credit http://taxes.marylandtaxes.com/Business_Taxes/General_Information/Business

Program_ _Tax_Credits/Green_Building_Tax_Credit.shtml

(Maryland,

United States;

2011)

Green Deals Covenants between the Government of the Netherlands and local businesses

(Netherlands; and households committed to reduce their greenhouse gas emissions. Strong

2011) focus on building energy efficiency.

http://www.government.nl/issues/energy-policy/green-deal

Green Door Reduced plan check turnaround time for energy-efficient and low-carbon

(Queensland, building projects.

Australia; $\quad$ http://statements.qld.gov.au/Statement/ld/75660

2011)

Green Leasing Technical support for and information on green leases.

Toolkit http://sustainca.org/green leases toolkit

(California,

United States;

2009)

Green Mark

Certification and classification instrument based on labelling.

(Singapore; http://www.greenmark.sg/

2005)

Green Permit Reduced plan check fees for energy-efficient and low-carbon building projects.

Program http://www.cityofchicago.org/city/en/depts/bldgs/supp info/overview of the

(Chicago, greenpermitprogram.html

United States;

2010)

Green RE Certification and classification instrument based on labelling.

(Green Real http://www.greenre.org/about-us.html

Estate)

(Malaysia;

2013)

Green Star Certification and classification instrument based on labelling.

(Australia; http://www.gbca.org.au/green-star/

2003)

Green Strata Technical support for and information on improved energy-efficiency and other

(Australia; sustainability aspects of common property of residential multi-unit properties.

2011) http://www.greenstrata.com.au/

Green Certification and classification instrument based on labelling for townships.

Townships http://www.greentownship.my/

(Malaysia;

2009) 
Table A - continued

\begin{tabular}{|c|c|}
\hline $\begin{array}{l}\text { GRIHA (Green } \\
\text { Rating for } \\
\text { Integrated } \\
\text { Habitat } \\
\text { Assessment) } \\
\text { (India; 2007) }\end{array}$ & $\begin{array}{l}\text { Certification and classification instrument based on labelling. } \\
\text { http://grihaindia.org/ }\end{array}$ \\
\hline $\begin{array}{l}\text { LEED } \\
\text { (Leadership in } \\
\text { Energy and } \\
\text { Environmental } \\
\text { Design) } \\
\text { (global; 2000) }\end{array}$ & $\begin{array}{l}\text { Certification and classification instrument based on labelling. } \\
\text { http://www.usgbc.org/leed }\end{array}$ \\
\hline $\begin{array}{l}\text { LCCFA (Low } \\
\text { Carbon Cities } \\
\text { Framework } \\
\text { and } \\
\text { Assessment } \\
\text { System; } \\
\text { Malaysia; } \\
\text { 2011) }\end{array}$ & $\begin{array}{l}\text { Certification and classification instrument based on labelling. } \\
\text { http://esci-ksp.org/publication/low-carbon-cities-framework-and-assessment- } \\
\text { system/ }\end{array}$ \\
\hline $\begin{array}{l}\text { NABERS } \\
\text { (National } \\
\text { Australian } \\
\text { Built } \\
\text { Environment } \\
\text { Rating } \\
\text { System) } \\
\text { (Australia; } \\
\text { 1998) }\end{array}$ & $\begin{array}{l}\text { Certification and classification instrument based on labelling. } \\
\text { http://www.nabers.gov.au/public/WebPages/Home.aspx }\end{array}$ \\
\hline $\begin{array}{l}\text { National } \\
\text { Green Leasing } \\
\text { Policy } \\
\text { (Australia; } \\
\text { 2010) }\end{array}$ & $\begin{array}{l}\text { Commitment of Australian governments to use green leases for their office } \\
\text { space. } \\
\text { http://www.industry.gov.au/Energy/EnergyEfficiency/Non- } \\
\text { residentialBuildings/GovernmentBuildings/EnergyEfficiencyOperations/GLSGover } \\
\text { nmentBuildings/Pages/default.aspx }\end{array}$ \\
\hline $\begin{array}{l}\text { PACE } \\
\text { (Property } \\
\text { Assessed } \\
\text { Clean Energy) } \\
\text { (United } \\
\text { States; 2008) }\end{array}$ & $\begin{array}{l}\text { Tripartite financing for commercial building retrofits. } \\
\text { http://www.pacenow.org/ }\end{array}$ \\
\hline $\begin{array}{l}\text { Retrofit } \\
\text { Chicago } \\
\text { (Chicago, } \\
\text { United States; } \\
\text { 2012) }\end{array}$ & $\begin{array}{l}\text { Technical support for and information on commercial and residential building } \\
\text { retrofits. } \\
\text { http://www.cityofchicago.org/city/en/progs/env/retrofit chicago.html }\end{array}$ \\
\hline
\end{tabular}


Table A - continued

\begin{tabular}{|c|c|}
\hline $\begin{array}{l}\text { Small Business } \\
\text { Improvement } \\
\text { Fund } \\
\text { (Chicago, } \\
\text { United States; } \\
\text { 2000) }\end{array}$ & $\begin{array}{l}\text { Financial assistance for building retrofits. } \\
\text { http://somercor.com/sbif/ }\end{array}$ \\
\hline $\begin{array}{l}\text { Sunny Leasing } \\
\text { (Netherlands; } \\
\text { 2012) }\end{array}$ & $\begin{array}{l}\text { Technical support for and information on energy-efficiency upgrades of } \\
\text { residential property in the commercial and social rental sector. } \\
\text { http://www.zonnighuren.nl/ (in Dutch only) }\end{array}$ \\
\hline $\begin{array}{l}\text { Supply Chain } \\
\text { Sustainability } \\
\text { (Australia; } \\
\text { 2015) }\end{array}$ & $\begin{array}{l}\text { Online platform to improve environmental sustainability knowledge in the } \\
\text { construction sector. } \\
\text { http://www.supplychainschool.org.au/ }\end{array}$ \\
\hline $\begin{array}{l}\text { Sustainable } \\
\text { Business } \\
\text { Leader } \\
\text { Program } \\
\text { (Boston, } \\
\text { United States; } \\
\text { 2007) }\end{array}$ & $\begin{array}{l}\text { Certification and classification instrument based on rating for commercial } \\
\text { building users. } \\
\text { http://sustainablebusinessleader.org/ }\end{array}$ \\
\hline $\begin{array}{l}\text { Sustainable } \\
\text { Public } \\
\text { Procurement } \\
\text { (Netherlands; } \\
\text { 2010) }\end{array}$ & $\begin{array}{l}\text { Commitment of governments in the Netherlands to achieve } 100 \text { per cent } \\
\text { environmental sustainable procurement of their office materials and workspace } \\
\text { by } 2015 \text {. } \\
\text { https://www.pianoo.nl/themas/maatschappelijk-verantwoord-inkopen- } \\
\text { duurzaam-inkopen (in Dutch only) }\end{array}$ \\
\hline
\end{tabular}

Note: Hyperlinks last checked on 24 November 2015. 
Table B - Summary of instruments studied

\begin{tabular}{|c|c|c|c|c|c|c|c|c|c|c|c|c|c|}
\hline & \multicolumn{4}{|c|}{ Instrument type } & \multicolumn{3}{|c|}{ Building type } & \multicolumn{3}{|c|}{ Building stage } & \multicolumn{3}{|c|}{ Focus } \\
\hline & $A$ & B & C & D & 1 & 2 & 3 & 1 & 2 & 3 & 1 & 2 & 3 \\
\hline 1000 & & & & $x$ & & & & & & & & & \\
\hline Superintendents & & & & & & & $x$ & & $x$ & & & & $x$ \\
\hline 1200 Buildings & & & $x$ & & $x$ & & & & $x$ & & $x$ & & \\
\hline $\begin{array}{l}\text { Amsterdam } \\
\text { Investment Fund }\end{array}$ & & & $x$ & & $x$ & & & & & $x$ & $x$ & & \\
\hline $\begin{array}{l}\text { Better Buildings } \\
\text { Challenge }\end{array}$ & & $x$ & & & $x$ & & & & $x$ & & $x$ & & \\
\hline $\begin{array}{l}\text { Better Building } \\
\text { Partnership }\end{array}$ & & $x$ & & & $x$ & & & & $x$ & & $x$ & & \\
\hline $\begin{array}{l}\text { Billion Dollar } \\
\text { Green Challenge }\end{array}$ & & & $x$ & & $x$ & & & & $x$ & & $x$ & & \\
\hline BREEAM & $x$ & & & & & & $x$ & $x$ & & & $x$ & & \\
\hline $\begin{array}{l}\text { Building } \\
\text { Innovation Fund }\end{array}$ & & & $x$ & & $x$ & & & & $x$ & & $x$ & & \\
\hline $\begin{array}{l}\text { Can. Renewable } \\
\text { and Conservation } \\
\text { Exp. }\end{array}$ & & & $x$ & & $x$ & & & $x$ & & & $x$ & & \\
\hline $\begin{array}{l}\text { Chicago Green } \\
\text { Office Challenge }\end{array}$ & & $x$ & & & $x$ & & & & $x$ & & & $x$ & \\
\hline $\begin{array}{l}\text { CitySwitch Green } \\
\text { Office }\end{array}$ & & $x$ & & & $x$ & V & & & $x$ & & & $x$ & \\
\hline $\begin{array}{l}\text { Climate Change } \\
\text { Sector } \\
\text { Agreements }\end{array}$ & & & & $x$ & $x$ & & & & & $x$ & & & $\mathrm{x}$ \\
\hline $\begin{array}{l}\text { ClimateSmart } \\
\text { Home Service }\end{array}$ & & $x$ & & & & $x$ & & & $x$ & & $x$ & & \\
\hline $\begin{array}{l}\text { Common Carbon } \\
\text { Metric }\end{array}$ & & $x$ & & & & & $x$ & & & & $x$ & & \\
\hline $\begin{array}{l}\text { Density Bonuses } \\
\text { North Carolina }\end{array}$ & & & & $x$ & & & $x$ & $x$ & & & $x$ & & \\
\hline E+Green Building & & $x$ & & & & $x$ & & $x$ & & & $x$ & & \\
\hline Eco Housing & $x$ & & & & & $x$ & & $x$ & & & $x$ & & \\
\hline Eco-Office & $x$ & & & & $x$ & & & $x$ & & & & $x$ & \\
\hline $\begin{array}{l}\text { Energy Efficiency } \\
\text { Mortgage }\end{array}$ & & & $x$ & & & $x$ & & $x$ & & & $x$ & & \\
\hline $\begin{array}{l}\text { Energy } \\
\text { Experience } \\
\text { Programme }\end{array}$ & & & $x$ & & & $x$ & & & $x$ & & & $x$ & \\
\hline
\end{tabular}


Table B - continued

\begin{tabular}{|c|c|c|c|c|c|c|c|c|c|c|c|c|c|}
\hline & \multicolumn{4}{|c|}{ Instrument type } & \multicolumn{3}{|c|}{ Building type } & \multicolumn{3}{|c|}{ Building stage } & \multicolumn{3}{|c|}{ Focus } \\
\hline & $A$ & B & C & D & 1 & 2 & 3 & 1 & 2 & 3 & 1 & 2 & 3 \\
\hline Energy Leap & \multicolumn{4}{|c|}{$x$} & & & $x$ & & & $x$ & & & $\mathrm{x}$ \\
\hline Energy Star & $x$ & & & & \multirow{2}{*}{\multicolumn{3}{|c|}{$\mathrm{x}$}} & \multirow{2}{*}{\multicolumn{3}{|c|}{$x$}} & \multirow{2}{*}{\multicolumn{3}{|c|}{$\mathrm{x}$}} \\
\hline Buildings & & & & & & & & & & & & & \\
\hline Energy Star Homes & $x$ & & & & \multicolumn{3}{|c|}{$\mathrm{x}$} & \multicolumn{3}{|l|}{$x$} & \multicolumn{3}{|c|}{$x$} \\
\hline EnviroDevelopment & $x$ & & & & \multicolumn{3}{|c|}{$x$} & \multicolumn{3}{|l|}{$x$} & \multicolumn{3}{|c|}{$x$} \\
\hline Environmental & & & $x$ & & \multirow{3}{*}{\multicolumn{3}{|c|}{$\mathrm{x}$}} & \multirow{3}{*}{\multicolumn{3}{|c|}{$x$}} & \multirow{3}{*}{\multicolumn{3}{|c|}{$x$}} \\
\hline Upgrade & & & & & & & & & & & & & \\
\hline Agreements & & & & & & & & & & & & & \\
\hline ESCO Accreditation & \multirow{2}{*}{\multicolumn{4}{|c|}{$x$}} & \multirow{2}{*}{\multicolumn{3}{|c|}{$x$}} & \multirow{2}{*}{\multicolumn{3}{|c|}{$\mathrm{x}$}} & \multirow{2}{*}{\multicolumn{3}{|c|}{$\mathrm{x}$}} \\
\hline Scheme & & & & & & & & & & & & & \\
\hline Green Building & \multirow{2}{*}{\multicolumn{3}{|c|}{ 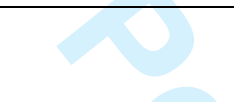 }} & \multirow[t]{2}{*}{$x$} & & & & & & & & & \\
\hline Incentive Program & & & & & & & $x$ & $x$ & & & $\mathrm{x}$ & & \\
\hline Green Building & $x$ & & & & & & & & & & & & \\
\hline Index & & & & & & & $x$ & $x$ & & & $x$ & & \\
\hline Green Building Tax & & & & $x$ & & & & & & & & & \\
\hline Credit Program & & & & & & & $x$ & & & $x$ & $\mathrm{x}$ & & \\
\hline Green Deals & & $x$ & & & 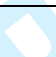 & & $x$ & & & $\mathrm{x}$ & & & $x$ \\
\hline Green Door & & & & $x$ & $x$ & & & $x$ & & & $\mathrm{x}$ & & \\
\hline Green Leasing & & & & $x$ & 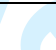 & & & & & & & & \\
\hline Toolkit & & & & & $x$ & & & & & $\mathrm{x}$ & $\mathrm{x}$ & & \\
\hline Green Mark & $x$ & & & & & 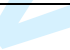 & $x$ & & & $x$ & $\mathrm{x}$ & & \\
\hline Green Permit & & & & $x$ & & & 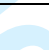 & & & & & & \\
\hline Program & & & & & & & $x$ & & & $\mathrm{x}$ & $\mathrm{x}$ & & \\
\hline Green RE & $x$ & & & & & & $x$ & $x$ & & & $\mathrm{x}$ & & \\
\hline Green Star & $x$ & & & & & & $x$ & $x$ & & & $\mathrm{x}$ & & \\
\hline Green Strata & & $x$ & & & & $x$ & & & $x$ & & & & $\mathrm{x}$ \\
\hline Green Townships & $x$ & & & & & $x$ & & $x$ & & & $x$ & & \\
\hline GRIHA & $x$ & & & & & & $x$ & $x$ & 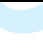 & 2. & $x$ & & \\
\hline LEED & $x$ & & & & $x$ & & & $x$ & $\bar{s}$ & 2 & $x$ & & \\
\hline LCCFA & $x$ & & & & & & $x$ & $x$ & & 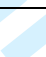 & $\mathrm{x}$ & & \\
\hline NABERS & $x$ & & & & $x$ & & & & & $x$ & $\mathrm{x}$ & & \\
\hline National Green & & & & $x$ & & & & & & & & & \\
\hline Leasing Policy & & & & & $x$ & & & & $\mathrm{x}$ & & $\mathrm{x}$ & & \\
\hline PACE & & & $\mathrm{x}$ & & $x$ & & & & $x$ & & $x$ & & \\
\hline Retrofit Chicago & & $x$ & & & $\mathrm{x}$ & & & & $x$ & & $x$ & & \\
\hline
\end{tabular}


Table B - continued

\begin{tabular}{|c|c|c|c|c|c|c|c|c|c|c|c|c|c|}
\hline & \multicolumn{4}{|c|}{ Instrument type } & \multicolumn{3}{|c|}{ Building type } & \multicolumn{3}{|c|}{ Building stage } & \multicolumn{3}{|c|}{ Focus } \\
\hline & $A$ & B & $\mathrm{C}$ & $\mathrm{D}$ & 1 & 2 & 3 & 1 & 2 & 3 & 1 & 2 & \\
\hline $\begin{array}{l}\text { Small Business } \\
\text { Improvement } \\
\text { Fund }\end{array}$ & & & $\mathrm{x}$ & & $\mathrm{x}$ & & & & $\mathrm{x}$ & & $x$ & & \\
\hline Sunny Leasing & & $x$ & & & & $\mathrm{x}$ & & & $x$ & & $x$ & & \\
\hline $\begin{array}{l}\text { Supply Chain } \\
\text { Sustainability }\end{array}$ & & & & $x$ & $\mathrm{x}$ & & & & & $x$ & & & $\mathrm{x}$ \\
\hline $\begin{array}{l}\text { Sustainable } \\
\text { Business Leader } \\
\text { Program }\end{array}$ & $x$ & & & & $\mathrm{x}$ & & & & $x$ & & $x$ & & \\
\hline $\begin{array}{l}\text { Sustainable Public } \\
\text { Procurement }\end{array}$ & & & & $x$ & $\mathrm{x}$ & & & $\mathrm{x}$ & $\mathrm{x}$ & & $\mathrm{x}$ & & \\
\hline Total & 17 & 12 & 10 & 11 & 25 & 10 & 15 & 20 & 20 & 10 & 40 & 4 & 6 \\
\hline percentage & $\begin{array}{l}34 \\
\%\end{array}$ & $\begin{array}{l}24 \\
\%\end{array}$ & $\begin{array}{l}20 \\
\%\end{array}$ & $\begin{array}{l}22 \\
\%\end{array}$ & $\begin{array}{l}50 \\
\%\end{array}$ & $\begin{array}{l}20 \\
\%\end{array}$ & $\begin{array}{l}30 \\
\%\end{array}$ & $\begin{array}{l}40 \\
\%\end{array}$ & $\begin{array}{l}40 \\
\%\end{array}$ & $\begin{array}{l}20 \\
\%\end{array}$ & $\begin{array}{l}80 \\
\%\end{array}$ & $\begin{array}{l}8 \\
\%\end{array}$ & $\begin{array}{l}12 \\
\%\end{array}$ \\
\hline
\end{tabular}

Abbreviations:

- Instrument $\mathrm{A}=$ certification and classification; instrument type $\mathrm{B}=$ information generation and dissemination; instrument type $C=$ financing; instrument type $D=$ accelerators and bridging.

- Building type 1 = commercial buildings; building type 2 = residential buildings; building type $3=$ both commercial and residential.

- Building stage 1 = new buildings; building type 2 = existing buildings; building type 3 = both new and existing.

- Focus 1 = technological solutions; focus 2 = behavioural change; focus $3=$ both technological solutions and behavioural change. 